\title{
Incidence of "new-onset" constipation and associated factors during lockdown due to the coronavirus-19 pandemic.
}

Jose María Remes-Troche ( $\nabla$ jose.remes.troche@gmail.com )

Laboratorio de Fisiología Digestiva y Motilidad Gastrointestinal, Instituto de Investigaciones MédicoBiológicas, Universidad Veracruzana México

\section{Enrique Coss-Adame}

Departamento de Gastroenterología, Instituto Nacional de Ciencias Médicas y Nutrición Salvador Zubirán

\section{Mercedes Amieva-Balmori}

Laboratorio de Fisiología Digestiva y Motilidad Gastrointestinal, Instituto de Investigaciones MédicoBiológicas, Universidad Veracruzana México

\section{José Antonio Velarde-Ruiz Velasco}

Hospital Civil de Guadalajara Fray Antonio Alcalde, Guadalajara, México

\section{Paulo César Gómez-Castaños}

Centro de Investigación y Docencia en Ciencias de la Salud, Universidad Autónoma de Sinaloa, Culiacán,

Sinaloa.

\section{Ricardo Flores-Rendón}

Instituto de Seguridad y Servicios Sociales de los Trabajadores del Estado y Municipios de Baja California, Servicio de Gastroenterología y Endoscopia, Hospital Mexicali

\section{Octavio Gómez-Escudero}

Clínica de Gastroenterología, Endoscopia Digestiva y Motilidad Gastrointestinal "Endoneurogastro", Hospital Ángeles Puebla

\section{María Celina Rodríguez-Leal}

Departamento de Gastroenterología, IMSS Unidad Médica de Alta Especialidad 25 Monterrey

\section{Cristina Durán-Rosas}

Laboratorio de Fisiología Digestiva y Motilidad Gastrointestinal, Instituto de Investigaciones MédicoBiológicas, Universidad Veracruzana México

\section{Samanta Mayanin Pinto-Gálvez}

Laboratorio de Fisiología Digestiva y Motilidad Gastrointestinal, Instituto de Investigaciones MédicoBiológicas, Universidad Veracruzana México

\section{Bryan Adrián Priego-Parra}


Laboratorio de Fisiología Digestiva y Motilidad Gastrointestinal, Instituto de Investigaciones MédicoBiológicas, Universidad Veracruzana México

\section{Arturo Triana-Romero}

Laboratorio de Fisiología Digestiva y Motilidad Gastrointestinal, Instituto de Investigaciones MédicoBiológicas, Universidad Veracruzana México

\section{Research Article}

Keywords: constipation, COVID-19, pandemic, Mexico, water, fiber

Posted Date: September 16th, 2020

DOI: https://doi.org/10.21203/rs.3.rs-77783/v1

License: (c) (i) This work is licensed under a Creative Commons Attribution 4.0 International License. Read Full License

Version of Record: A version of this preprint was published at BMJ Open Gastroenterology on September 16th, 2020. See the published version at https://doi.org/10.1136/bmjgast-2021-000729. 


\section{Abstract}

Background: A minimum of physical activity and low liquid intake are factors that have been associated with constipation. The health emergency brought on by the COVID-19 pandemic has resulted in adopting behavior, such as sheltering-in-place (less mobility) and dietary changes, creating a scenario we believe to be an adequate model for examining the appearance of symptoms of constipation and its associated factors.

Methods: A cross-sectional and descriptive study was conducted on an open population, applying an electronic survey (4 weeks after lockdown due to COVID-19 in Mexico) to evaluate: demographic characteristics, physical activity, water and fiber intake, appearance of constipation symptoms (including stool consistency), and quality of life.

Key results: Out of 678 subjects evaluated, $170(25 \%, 95 \% \mathrm{Cl} 21.7-28.4)$ developed symptoms of "newonset" constipation, with a significant decrease in the number of daily bowel movements $(p<0.05)$ and hardness of stool consistency $(p<0.05)$ during lockdown. The multivariate analysis (logistic regression) showed that female sex $(p=0.001)$, water intake $(p=0.039)$, and physical activity $(p=0.012)$ were associated with "new-onset" constipation.

Conclusions: Reduced physical activity and less water intake due to mobility restrictions imposed for epidemiologic reasons, such as a pandemic, can lead to symptoms of "new-onset" constipation.

\section{Introduction}

Constipation is one of the most frequent gastrointestinal disorders and is estimated to affect up to $14 \%$ of the general population. $[1,2,3,4]$ The pathophysiology of constipation is complex and multifactorial. $[1,5,6]$ Among the factors that contribute to the appearance or worsening of constipation symptoms are those that are considered unmodifiable, such as female sex, advanced age, medication use, and the association with different comorbidities, such as neurologic diseases.[7] On the other hand, there are numerous factors, associated with lifestyle, that are considered modifiable, such as low fiber intake,[8,9] inadequate water intake,[10,11,12] sedentary lifestyle, and reduced physical activity.[12,13] Nevertheless, evidence on the theme is limited and controversial, given the difficulty in conducting prospective studies on the topic. Some studies have demonstrated that physical activity has no effect on the motor activity of the colon, whereas others report the opposite, showing it can depend on the frequency, intensity, and duration of exercise (for example, marathon running). $[11,13,14]$ Symptoms of constipation induced by immobility in geriatric patients have been shown to decrease with the regular performance of physical activity. In a unique study on the subject, lovino et al.[15] demonstrated that prolonged physical inactivity (for 35 days, in 10 healthy volunteers) triggered constipation in $60 \%$ of the study individuals. 
The COVID-19 pandemic, caused by the SARS-CoV-2 coronavirus and declared in March 2019 by the World Health Organization (WHO), has resulted in an unprecedented public health crisis worldwide.[16] This health emergency has produced substantial changes in social, economic, and cultural spheres. In Mexico, contingency measures (reduced essential activity, physical distancing, stay-at-home orders, etc.) were established on April 21, 2020. Evidence suggests that the obligatory social self-isolation impacts the lifestyle of the population, forcing the adoption of unhealthy dietary habits (increased ultra- processed and refined foods and decreased fruit and vegetable intake), sedentary behavior, and sleep disturbances. [17]

At present, there are no reports in the literature that establish a relation between a change in bowel movement habit and being under the current lockdown. Thus, the aim of our study was to evaluate the incidence of symptoms of constipation and associated factors during the lockdown implemented to contain the spread of COVID-19 in Mexico.

\section{Methods}

\section{Study design and population}

A descriptive, cross-sectional study was conducted on an adult Mexican population (above 18 years of age), in which volunteers were asked to take a survey that was distributed on social media throughout Mexico. The survey was designed and applied utilizing the "Google Forms" tool. Because the lockdown (phase 3 of the pandemic) was put in place in Mexico on April 21, 2020, the survey became available on May 18, 2020 (four weeks later), after obtaining informed consent from the volunteers that wished to participate, along with their authorization of personal data use, ensuring data privacy.

There was no incentive for completing the survey.

\section{Data collection}

The following data were collected in the survey applied to each of the participants:

a. Sociodemographic characteristics: Sex, age, weight, height, body mass index (BMI), educational level, comorbidities, and medication

b. Physical activity before and after the lockdown: Based on the international physical activity questionnaire-short form (IPAQ-SF),[18] physical activity frequency (days per week), type, intensity (1=zero, 2=mild [walking, jogging],3=moderate [riding a bicycle, using a treadmill, etc.], 4=intense [CrossFit, aerobics, working out at a gym, etc.]), and duration ( $<30$ minutes per day, 30 to 60 minutes per day, 61 to 90 minutes per day, 91 to 120 minutes per day, and more than 120 minutes per day).

c. Water and fiber intake before and after the lockdown: Water intake was evaluated according to the 4 following categories: 1) < $500 \mathrm{ml}$ per day, 2) $500 \mathrm{ml}$ to 1 liter per day, 3) 1 to 2.5 liters per day, and 4) $>2.5$ liters per day $(n, \%)$. Regarding fiber, the participant was asked if intake was on a regular basis 
and in what form it was consumed (cereals, fruits and vegetables, supplements in capsules, supplements in powder).

d. Constipation symptoms, stool consistency, and bowel movement frequency: The participants were asked in binary form (yes or no) if they considered themselves to have constipation before the lockdown. The participants with prior symptoms of constipation were excluded. Those that answered that they had not previously presented with constipation were asked, "Do you think you have developed constipation symptoms since the lockdown was put in place?" In addition, based on the questions for defining chronic constipation from the Rome IV modular questionnaire, the following symptoms were evaluated: straining, pushing force needed to defecate, stool consistency types 1 and 2, according to the Bristol stool form scale, in more than $25 \%$ of the bowel movements, and use of digital maneuvers. The participants were also asked the number of bowel movements they had per day and per week, and the average stool consistency, according to the Bristol scale, in the past

e. Quality of life in relation to constipation. The patient assessment of constipation-quality of life (PAC$\mathrm{QOL})$ questionnaire was used because it is the most widely validated, specific tool for measuring quality of life in patients with constipation.[19] It has been validated and used in Spanish[20] and consists of

28 items grouped into the following subscales: (a) physical discomfort, b) psychosocial discomfort, c) preoccupation, and d) treatment satisfaction, and includes an overall score. Scoring is on a Likert scale of 5 points, from 0 (nothing/never) to 4 (extremely, always), and a lower score reflects a better quality of life.

\section{Statistical analysis}

Incidence (new cases) of constipation after the lockdown ("new-onset" constipation) was calculated and the $95 \% \mathrm{Cl}$ was reported. A comparative analysis of the categorical variables and continuous variables was carried out between the participants with "new- onset" constipation and those with no constipation during the lockdown, utilizing the Student's t test, the Mann-Whitney $U$ test, the chi-square test, or the Wilcoxon test, as appropriate. Statistical significance was set a $p<0.05$. A multivariate analysis was then performed utilizing logistic regression, employing the enter model. The analysis of the results was carried out through descriptive statistics with the IBM ${ }^{\circledR}$ SPSS Statistics ${ }^{\circledR}$ version 22 program. The protocol followed the Declaration of Helsinki stipulations for biomedical research and was approved by the institutional committee (IIMB-2020-008)

\section{Results}

\section{General population characteristics}

A total of 772 questionnaires were received, 94 of which were excluded (when more than one response was selected, survey takers were from countries other than Mexico, surveys were incompletely filled out, etc.), leaving 678 study participants. Of those subjects, 405 were women (59.7\%), 273 (40.3\%) were men, and the mean participant age was $31.21 \pm 11.9$ years (range 18-74). 
One hundred seventy subjects $(25 \%, 95 \% \mathrm{Cl} 21.7-28.4)$ reported having symptoms of constipation that appeared during the lockdown (Figure 1). The symptoms associated with constipation in those subjects were: hard stools in more than $25 \%$ of bowel movements in 131 (77\%) participants, sensation of incomplete defecation in $122(72 \%)$, sensation of straining in $114(67 \%)$, and use of digital maneuvers in 6 (3.5\%). The average stool consistency reported in the past week, according to the Bristol scale, was: type 1 in $20 \%(34)$, type 2 in $22 \%(n=38)$, type 3 in $22 \%(n=37)$, type 4 in $36(21 \%)$, type 5 in $15(9 \%)$, type 6 in $8(5 \%)$, and type 7 in $2(1.2 \%)$.

In those subjects, the median of bowel movements per day decreased from 2 (range 1-6) to 1 (range 1-6) after the lockdown $(p=0.00001)$. Likewise, the median of bowel movements per week decreased from 9 (range 3-35) to 7 (range 1-28) after the lockdown (Figure 2). The median of stool consistency, according to the Bristol scale, decreased from 4 (range 1-7) to 3 (range 1-6) after the lockdown $(p=0.0001)$. In contrast, in the subjects that did not develop constipation, there was no difference in the number of bowel movements per day (median 2 [range 1-7] vs 2 [range 1 to 10], $p=0.464$ ), in the number of bowel movements per week (median 12 [range 1-42] vs 10 [range 1 to 56], $p=0.225$ ), or in stool consistency (median 4 [range 1 to 7 ] vs 4 [range 1 to 6 ], $p=0.58$ ).

Regarding physical activity, the subjects that developed "new-onset" constipation, significantly reduced the number of days that they did exercise during the lockdown (median 4 [range 1 to 7 ] vs. median 2.5 [range 0 to 7], $p=0.004$ ). In contrast, there was no difference in the number of days doing exercise during the lockdown in the subjects that did not present with constipation (median 3 [range 0 to 7] vs. median 3 [range 0 to 7 ], $p=0.669$ )

\section{Factors associated with "new-onset" constipation before the lockdown}

Table 1 shows the baseline characteristics and associated factors (before the lockdown) in the 170 subjects with "new-onset" constipation and the 508 subjects that had no constipation symptoms. A significantly higher percentage of women than men developed "new-onset" constipation $(p=0.0001)$. The presence of comorbidities, water and fiber intake, physical activity, number of bowel movements, and Bristol scale-assessed stool consistency were similar between the two groups before the lockdown.

\section{Table 1.- Characteristics and risk factors in relation to lockdown}




\begin{tabular}{|c|c|c|c|c|}
\hline & $\begin{array}{c}\text { "New- } \\
\text { onset" constipation } \\
n=170\end{array}$ & $\begin{array}{c}\text { No } \\
\text { constipation } \\
n=508\end{array}$ & $\mathrm{p}=$ & $\begin{array}{c}\mathrm{OR} \\
(95 \% \mathrm{CI})\end{array}$ \\
\hline $\begin{array}{l}\text { Sex } \\
\text { - Women (n,\%) } \\
\text { - Men (n, \%) }\end{array}$ & $\begin{array}{l}132(78 \%) \\
38(22 \%)\end{array}$ & $\begin{array}{l}273(54 \%) \\
235(46 \%)\end{array}$ & $0.0000^{* *}$ & $2.99(2-4.4)$ \\
\hline Age, years (mean, SD) & $31 \pm 12$ & $31.4 \pm 12$ & 0.72 & ---- \\
\hline Body mass index (mean, SD) & $25.6 \pm 4.5$ & $26.3 \pm 5$ & 0.14 & ----- \\
\hline $\begin{array}{l}\text { Weight } \\
\text { - Underweight (n,\%) } \\
\text { - Normal (n,\%) } \\
\text { - Overweight (n,\%) } \\
\text { - Obesity }(n, \%)\end{array}$ & $\begin{array}{c}3(2 \%) \\
80(47 \%) \\
55(33 \%) \\
31(18 \%)\end{array}$ & $\begin{array}{c}10(2 \%) \\
215(43 \%) \\
177(35 \%) \\
104(20 \%)\end{array}$ & 0.744 & $\begin{array}{c}0.3(0.8-1.1) \\
0.37(0.2- \\
0.4) \\
0.31(0.2- \\
0.4) \\
0.29(.1-.4)\end{array}$ \\
\hline $\begin{array}{l}\text { Comorbidities } \\
\text { - DM (n\%) } \\
\text { - Hypothyroidism (n,\%) }\end{array}$ & $\begin{array}{l}3(1.7 \%) \\
4(2.3 \%)\end{array}$ & $\begin{array}{c}7(1.3 \%) \\
5(1 \%)\end{array}$ & $\begin{array}{c}0.71 \\
0.335\end{array}$ & $\begin{array}{l}1.2(0.3-5) \\
2.4(0.6-9)\end{array}$ \\
\hline $\begin{array}{l}\text { Medications } \\
\text { - Opioid use } \\
\text { - Antidepressants } \\
\text { - Anticonvulsants } \\
\text { - Calcium antagonists }\end{array}$ & $\begin{array}{c}0 \\
0 \\
1(0.6 \%) \\
2(1.2 \%)\end{array}$ & $\begin{array}{l}2(0.4 \%) \\
3(0.6 \%) \\
1(0.2 \%) \\
1(0.2 \%)\end{array}$ & $\begin{array}{l}0.74 \\
0.99 \\
0.831 \\
0.415\end{array}$ & $\begin{array}{l}1.4(0.13-16) \\
1(0.1-9.5) \\
3(.1-48) \\
6(.5-66)\end{array}$ \\
\hline Regular fiber intake $(n, \%)$ & $115(67 \%)$ & $346(68 \%)$ & 0.99 & $\begin{array}{c}1.01(0.7- \\
1.4)\end{array}$ \\
\hline $\begin{array}{l}\text { Type of fiber } \\
\text { - High-fiber cereals (n,\%) } \\
\text { - Fruits and vegetables (n,\%) } \\
\text { - Supplement in capsules (n,\%) } \\
\text { - Supplement in powder (n,\%) }\end{array}$ & $\begin{array}{c}36(21 \%) \\
73(43 \%) \\
1(.6 \%) \\
5(3 \%) \\
\end{array}$ & $\begin{array}{c}106(21 \%) \\
233(46 \%) \\
1(.2 \%) \\
6(1.2 \%) \\
\end{array}$ & 0.34 & $\begin{array}{l}0.3(0.2-0.4) \\
0.3(0.2-0.4) \\
1(0.6-15) \\
0.8(0.2-2.7) \\
\end{array}$ \\
\hline $\begin{array}{l}\text { Water intake }(\mathrm{n}, \%) \\
-<500 \mathrm{ml} \text { per day }(\mathrm{n}, \%) \\
-500 \mathrm{ml} \text { to } 1 \text { liter per day }(\mathrm{n}, \%) \\
-1 \text { to } 2.5 \text { liters per day }(\mathrm{n}, \%) \\
->2.5 \text { liters per day }(\mathrm{n}, \%)\end{array}$ & $\begin{array}{c}2(1 \%) \\
29(17 \%) \\
124(73 \%) \\
15(9 \%)\end{array}$ & $\begin{array}{c}18(4 \%) \\
91(18 \%) \\
338(64 \%) \\
61(12 \%)\end{array}$ & 0.222 & $\begin{aligned} \text { 1. } & (0.02- \\
& 0.4) \\
\text { 2. } & (0.2- \\
& 0.4) \\
\text { 3. } & (0.2- \\
& 0.4) \\
4 . & 0.2(0.1- \\
& 0.4)\end{aligned}$ \\
\hline $\begin{array}{l}\text { Physical activity before the lockdown } \\
\text { - Yes (n,\%) }\end{array}$ & $116(68 \%)$ & $310(61 \%)$ & 0.09 & $1.3(09 .-1.9)$ \\
\hline $\begin{array}{l}\text { Intensity of physical activity } \\
\text { - Zero }(\mathrm{n}, \%) \\
\text { - Mild }(\mathrm{n}, \%) \\
\text { - Moderate }(\mathrm{n}, \%) \\
\text { - Intense }(\mathrm{n}, \%)\end{array}$ & $\begin{array}{l}49(29 \%) \\
54(32 \%) \\
28(16 \%) \\
39(23 \%)\end{array}$ & $\begin{array}{c}181(36 \%) \\
117(23 \%) \\
92(18 \%) \\
118(23 \%)\end{array}$ & 0.122 & $\begin{array}{l}0.2(0.1-0.3) \\
0.4(0.3-0.6) \\
0.3(0.1-0.4) \\
0.3(0.2-0.4)\end{array}$ \\
\hline
\end{tabular}




\begin{tabular}{|c|c|c|c|c|}
\hline $\begin{array}{l}\text { - } 30 \text { to } 60 \text { minutes per day }(n, \%) \\
\text { - } 61 \text { to } 90 \text { minutes per day }(n, \%) \\
\text { - } 91 \text { to } 120 \text { minutes per day }(n, \%) \\
\text { - More than } 120 \text { minutes per day } \\
(n, \%)\end{array}$ & $\begin{aligned} 25 & (15 \%) \\
65 & (38 \%) \\
24 & (14 \%) \\
8 & (5 \%) \\
2 & (1 \%)\end{aligned}$ & $\begin{array}{c}61(12 \%) \\
154(30 \%) \\
80(16 \%) \\
31(6 \%) \\
12(2 \%)\end{array}$ & 0.43 & $\begin{array}{l}0.4(0.2-0.6) \\
0.4(0.3-0.5) \\
0.3(0.1-0.4) \\
0.2(0.1-0.5) \\
0.1(0.03- \\
0.7)\end{array}$ \\
\hline $\begin{array}{l}\text { Days of physical activity per week (mean, } \\
\text { SD) }\end{array}$ & $3.1 \pm 2.2$ & $2.78 \pm 2$ & 0.07 & ---- \\
\hline \multicolumn{5}{|l|}{ Bowel movement characteristics } \\
\hline - Bowel movements per day (mean, SD) & $1.9 \pm 1$ & $2 \pm .9$ & 0.288 & ----- \\
\hline - Bowel movements per week (mean, SD) & $11.2 \pm 6$ & $12 \pm 6$ & 0.178 & ----- \\
\hline $\begin{array}{l}\text { - Stool consistency according to the Bristol } \\
\text { scale }\end{array}$ & $3.7 \pm .7$ & $3.7 \pm .8$ & 0.497 & ---- \\
\hline
\end{tabular}

$\mathrm{OR}=$ odds ratio, $\mathrm{SD}=$ standard deviation. ${ }^{* *}$ chi-square test.

Factors associated with "new-onset" constipation during the lockdown

According to the univariate analysis, the patients that developed "new-onset" constipation had less physical activity during the lockdown, and if performed, it was at a lower intensity. A higher number of subjects with "new-onset" constipation drank less than 1 liter of water per day ( $30 \%$ vs $20 \%, p=0.000)$. No differences were found in the duration or number of days of physical activity or in fiber intake during the lockdown between the two groups (Table 2).

Table 2.- Risk factors during the lockdown 


\begin{tabular}{|c|c|c|c|c|}
\hline & $\begin{array}{c}\text { "New-onset" } \\
\text { constipation } \\
n=170 \\
\end{array}$ & $\begin{array}{c}\text { No } \\
\text { constipation } \\
\mathrm{n}=508 \\
\end{array}$ & $\mathrm{p}=$ & $\begin{array}{c}\text { OR } \\
(95 \% \mathrm{CI})\end{array}$ \\
\hline Regular fiber intake $(n, \%)$ & $115(67 \%)$ & $356(70 \%)$ & 0.55 & $\begin{array}{l}0.8(0.6- \\
1.2)\end{array}$ \\
\hline $\begin{array}{l}\text { Type of fiber } \\
\text { - High-fiber cereals (n,\%) } \\
\text { - Fruits and vegetables (n,\%) } \\
\text { - Supplement in capsules (n,\%) } \\
\text { - Supplement in powder }(n, \%)\end{array}$ & $\begin{array}{c}32(19 \%) \\
74(43 \%) \\
1(.6 \%) \\
8(5 \%)\end{array}$ & $\begin{array}{c}101(20 \%) \\
247(48 \%) \\
0 \\
8(2 \%)\end{array}$ & 0.09 & $\begin{array}{c}0.3(0.2- \\
0.4) \\
0.2(0.2- \\
0.3) \\
--- \\
1.0(0.3- \\
2.7)\end{array}$ \\
\hline $\begin{array}{l}\text { Water intake }(\mathrm{n}, \%) \\
\quad-<500 \mathrm{ml} \text { per day }(\mathrm{n}, \%) \\
\quad-500 \mathrm{ml} \text { to } 1 \text { liter per day }(\mathrm{n}, \%) \\
-1 \text { to } 2.5 \text { liters per day }(\mathrm{n}, \%) \\
->2.5 \text { liters per day }(\mathrm{n}, \%)\end{array}$ & $\begin{array}{c}2(1 \%) \\
49(29 \%) \\
101(59 \%) \\
18(11 \%)\end{array}$ & $\begin{array}{c}5(1 \%) \\
87(17 \%) \\
333(66 \%) \\
83(16 \%)\end{array}$ & $0.001 * *$ & $\begin{array}{c}2.5(0.4- \\
12.8) \\
1.7(1.2- \\
2.5) \\
3.2(2.6- \\
4.1) \\
4.6(2.7- \\
7.6)\end{array}$ \\
\hline Physical activity during the lockdown & & & & \\
\hline - Yes $(n, \%)$ & $91(53 \%)$ & $321(63 \%)$ & $0.03 * *$ & $\begin{array}{c}1.49(1.0- \\
2.1)\end{array}$ \\
\hline $\begin{array}{l}\text { Intensity of physical activity } \\
\text { - Zero }(\mathrm{n}, \%) \\
\text { - Mild }(\mathrm{n}, \%) \\
\text { - Moderate }(\mathrm{n}, \%) \\
\text { - Intense }(\mathrm{n}, \%)\end{array}$ & $\begin{array}{c}79(47 \%) \\
10(6 \%) \\
68(40 \%) \\
13(8 \%)\end{array}$ & $\begin{array}{c}187(36 \%) \\
63(12 \%) \\
193(38 \%) \\
65(13 \%)\end{array}$ & $0.011 * *$ & $\begin{array}{l}2.3(1.8-3) \\
6(3.2-12) \\
2.8(2.1- \\
3.7) \\
5(2.7-9)\end{array}$ \\
\hline 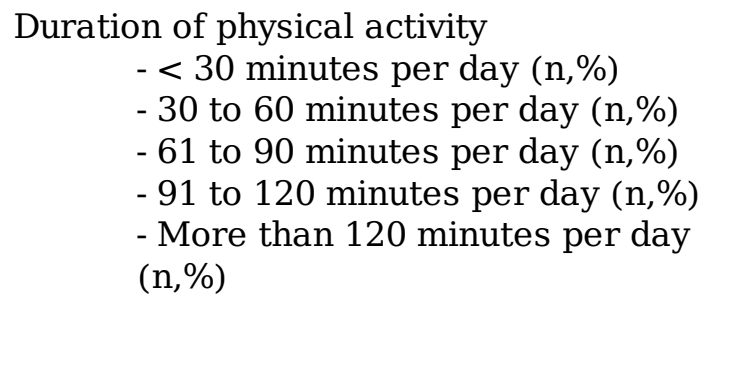 & $\begin{array}{c}34(20 \%) \\
51(30 \%) \\
13(8 \%) \\
2(1 \%) \\
1(0.6 \%)\end{array}$ & $\begin{array}{c}91(18 \%) \\
172(34 \%) \\
47(9 \%) \\
9(2 \%) \\
7(1.4 \%)\end{array}$ & 0.703 & $\begin{array}{c}2.6(1.8- \\
3.9) \\
3.3(2.4- \\
4.6) \\
3.6(1.9- \\
6.6) \\
4.5(0.9-20) \\
7(0.8-56)\end{array}$ \\
\hline $\begin{array}{l}\text { Days of physical activity per week (mean, } \\
\text { SD) }\end{array}$ & $2.46 \pm 2.3$ & $2.7 \pm 2.3$ & 0.185 & --- \\
\hline $\begin{array}{l}\text { Bowel movement characteristics } \\
\text { - Bowel movements per day (mean, SD) } \\
\text { - Bowel movements per week (mean, SD) } \\
\text { - Consistency according to the Bristol } \\
\text { scale }\end{array}$ & $\begin{array}{c}1.5 \pm 0.8 * \\
8.01 \pm 5.2 * \\
2.9 \pm 1.4 *\end{array}$ & $\begin{array}{c}2.06 \pm 1.2 \\
12.1 \pm 6.8 \\
3.9 \pm .89\end{array}$ & $\begin{array}{l}0.000 \\
0.000 \\
0.000\end{array}$ & $\begin{array}{l}--- \\
---- \\
----\end{array}$ \\
\hline
\end{tabular}

$\mathrm{OR}=$ odds ratio, $\mathrm{SD}=$ standard deviation. ${ }^{*}$ Student's $\mathrm{t}$ test, ${ }^{* *}$ chi-square test

In the multivariate analysis (logistic regression), female sex, water intake, and physical activity were associated were associated with the development of "new-onset" constipation (Table 3). 
Coefficients $^{\mathrm{a}}$

\begin{tabular}{|c|c|c|c|c|c|c|c|}
\hline \multirow[t]{2}{*}{ Model } & \multicolumn{2}{|c|}{$\begin{array}{l}\text { Non-standardized } \\
\text { coefficients }\end{array}$} & \multirow{2}{*}{$\begin{array}{c}\begin{array}{c}\text { Typified } \\
\text { coefficients }\end{array} \\
\text { Beta }\end{array}$} & \multirow[t]{2}{*}{$\mathrm{t}$} & \multirow[t]{2}{*}{ Sig. } & \multicolumn{2}{|c|}{$\begin{array}{l}95.0 \% \text { confidence interval for } \\
\text { B }\end{array}$} \\
\hline & B & Error & & & & Lower limit & Upper limit \\
\hline Sex & -.360 & .067 & -.204 & -5.369 & .000 & -.492 & -.228 \\
\hline Physical activity & -.168 & .067 & -.095 & -2.525 & .012 & -.299 & -.037 \\
\hline $\begin{array}{l}\text { Quantity of } \\
\text { water }\end{array}$ & -.110 & .053 & -.079 & -2.071 & .039 & -.215 & -.006 \\
\hline
\end{tabular}

a. Dependent variable: "new-onset" constipation

\section{Quality of life according to the PAC-QOL questionnaire}

Figure 3 shows the means of the 4 subscales and the overall score of the PAC-QOL questionnaire (Figure 3 ). The mean score for the physical discomfort subscale was $2.16 \pm 0.72$, for the psychosocial subscale was $1.74 \pm 0.6$, for the preoccupation subscale was $2.98 \pm 0.8$, for the satisfaction subscale was $3.46 \pm$ 0.9 , and for the overall score was $2.3 \pm 0.6$.

\section{Discussion}

Our study findings are novel, in the sense that for the first time, 1 out of every 4 (25\%) subjects whose physical activity was forcibly reduced as a consequence of the COVID-19 pandemic were shown to have developed "new-onset" constipation. The lockdown and mobility restriction measures put in place to contain the spread of COVID- 19 created a "natural" model, in which, according to our results, reduced physical activity and lower water intake were determining factors for the appearance of constipation.

In the subjects with "new-onset" constipation, there was a significant decrease in the number of bowel movements, as well as significantly harder stools during the lockdown. Very importantly, the fact that we found an increased occurrence of harder stools, utilizing the Bristol scale, which is an objective surrogate measure of colon transit, indicates that colon transit time was slower in those subjects during the lockdown.

The role of mobility and physical activity in relation to chronic constipation is a subject of debate,[12,13] but our study showed that reduced physical activity was a determining factor for the appearance of constipation symptoms. Numerous studies have reported that prolonged immobilization is a trigger for the appearance of symptoms of constipation.[21,22] Even though those findings have been described in chronically ill patients, little is known about reduced mobility and the appearance of constipation in a population that previously was apparently healthy, such as the one we evaluated. Our results are similar to those reported by lovino et al.,[15] in a "new-onset" constipation model. Those authors demonstrated that strict bedrest for a period of 35 days, adhered to even to perform daily activities, including defecation, was associated with a high rate of constipation in healthy volunteers. 
There is no doubt that exercise and physical activity have a beneficial impact on the physiology of the colon. Both have been shown to accelerate gastrointestinal transit,[23,24] increase colon motility, and even produce favorable hormonal changes, thus preventing constipation.[10,25] Nevertheless, it is important to recognize that there are other determining factors, such as the type and intensity of physical activity, as well as water and fiber intake. In that context, we found that $15 \%$ of the subjects with "newonset" constipation stopped doing exercise during the lockdown ( $68 \%$ before vs $53 \%$ after), whereas the rest of the subjects with constipation symptoms that did do exercise, reduced the frequency and intensity of their physical activity.

Another interesting finding of our study was that a significant number of subjects that developed constipation drank less than 1 liter of water per day. That result was similarly described in a population study conducted in the United States by Markland et al.[12] They reported that low liquid intake $(<1,882 \mathrm{ml}$ per day) was a predictor for constipation in women (prevalence odds ratio (POR): $1.3,95 \% \mathrm{Cl} 1.0,1.6)$ and men (POR: $2.4,95 \% \mathrm{Cl}$ 1.5,3.9). The mechanisms by which appropriate liquid intake positively influences colon transit are variable and include a better general hydration status and it can potentiate the effect of fiber and reduce its secondary effects.[26,27,28] With respect to fiber, as in other studies,[12] we found no relation between fiber intake and the appearance of "new-onset" constipation symptoms. However, we did not utilize a specific tool for fiber intake, unlike other population studies, which could be a source of bias in our study. Regarding the quality of life of the subjects that developed constipation, were found that the mean scores in the subscales and overall score of the PAC-QOL reflected a negative impact on the quality of life of those patients, even in the short span of symptom progression.

Even though ours is a novel study with relevant findings, it also has limitations. The appearance of "newonset" constipation symptoms does not necessarily imply that they will persist chronically and classified as chronic constipation according to Rome IV criteria, and in some subjects, the symptoms will probably disappear once their pre-lockdown physical activity and habits are re-established. Our study also was focused primarily on evaluating constipation symptoms, without taking abdominal pain into account, making it likely that some of our subjects actually had IBS-C. With respect to the tools utilized, the quantity of water was evaluated through an arbitrarily created Likert scale, considering that normal water intake should be at least 1 liter per day. Likewise, the null association between fiber intake and constipation was related to the fact that we did not employ a specific questionnaire for its appropriate evaluation. Finally, psychological comorbidities were not accounted for as these have been shown to have increased during COVID and may have acted as confounders.

In conclusion, in our study on an open population in Mexico, we found that one- fourth of the population that reduced their physical activity and drank less water due to mobility restrictions imposed for epidemiologic reasons, in the face of the COVID-19 pandemic, developed "new-onset" constipation symptoms. Given those results, appropriate physical activity and adequate liquid intake during prolonged periods of lockdown should be recommended to prevent said symptoms.

\section{Declarations}




\section{Authorship Statement}

Guarantor of the article: JMRT

Specific author contribution: JMRT and CDR wrote the paper. JMRT, ECA and MAB designed the research study and analyzed the data. CDR, BAPP, SMPP, ATR and CAAR performed the research tools and electronic platform. ECA, MAB, PCGC, JAVRV, RFR, OGE and MCRL collected the data.

Financial support: No financial support was received.

\section{Conflict of interest.}

José María Remes Troche is a member of the advisory board of Takeda, Asofarma, and Biocodex. He has been a speaker for Takeda, Asofarma, Medtronic, Carnot, and Alfasigma.

Enrique Coss-Adame has been a speaker for Takeda, Asofarma, Medtronic, Carnot, y Grünenthal.

Mercedes Amieva-Balmori has been a speaker for Takeda and Asofarma.

José Antonio Velarde-Ruiz Velazco has no conflict of interest.

Paulo César Gómez-Castaños has no conflict of interest.

Ricardo Flores-Rendón has no conflict of interest.

Octavio Gómez Escudero has no conflict of interest.

María Celina Rodríguez-Leal has no conflict of interest.

Cristina Durán-Rosas has no conflict of interest.

Samanta Mayanin Pinto-Gálvez has no conflict of interest.

Bryan Adrián Priego-Parra has no conflict of interest.

Arturo Triana-Romero has no conflict of interest.

\section{References}

1.- Suares NC, Ford CA. Prevalence of, and risk factors for, chronic idiopathic constipation in the community: systematic review and meta-analysis. Am J Gastroenterol. 2011;106(9):1582-91.

2.- Remes-Troche JM, Tamayo de la Cuesta JL, Raña-Garibay R, et al. Guías de diagnóstico y tratamiento del estreñimiento en México. A) Epidemiología (meta-análisis de la prevalencia), fisiopatología y clasificación. Rev Gastroenterol Mex. 2011;2(76):126-132. 
3.- Schmulson M, Ortíz O, Santiago-Lomelí M, et al. Frequency of functional bowel disorders among healthy volunteers in Mexico City. Dig Dis. 2006;24:342-7.

4.- Icaza-Chávez MA, Palomo-Torres BE, Paredes-Uc JA, et al. Epidemiología del estreñimiento. En: RemesTroche JM, editor. Síntomas gastrointestinales en México. Un estudio epidemiológico en México. SIGAME. México D.F.: Asecom Editores; 2015. p. 114-39.

5.- Remes-Troche JM, Coss-Adame E, Lopéz-Colombo A, et al. Consenso mexicano sobre estreñimiento crónico. Rev Gastroenterol Mex. 2018;83(2):168-189.

6.- Ruiz-López MC, Coss-Adame E. Calidad de vida en pacientes con diferentes subtipos de estreñimiento de acuerdo a los criterios de ROMA III. Rev Gastroenterol Mex.2015;80(1):13-20.

7.- Bharucha AE, Lacy BE. Mechanisms, evaluation, and management of chronic constipation. Gastroenterology. 2020;158(5):1232-1249.

8.- Yurtdaş G, Acar-Tek N, Akbulut G, et al. Risk factors for constipation in adults: a cross-sectional study. J Am Coll Nutr. 2020;20:1-7.

9.- Sandler RS, Jordan MC, Shelton BJ. Demographic and dietary determinants of constipation in the US population. Am J Public Health. 1990;80(2):185-189.

10.- Dukas L, Willett WC, Giovannucci EL. Association between physical activity, fiber intake, and other lifestyle variables and constipation in a study of women. Am J Gastroenterol. 2003; 98(8):1790-1796.

11.- Klauser AG, Peyerl C, Schindlbeck NE, Muller-Lissner SA. Nutrition and physical activity in chronic constipation. Eur J Gastroenterol Hepatol. 1992;4:227-233.

12.- Markland AD, Palsson O, Goode PS, Burgio KL, Busby- Whitehead J, Whitehead WE. Association of low dietary intake of fiber and liquids with constipation: evidence from the National Health and Nutrition Examination Survey. Am J Gastroenterol.2013;108(5):796-803.

13.- Wilson PB. Associations between physical activity and constipation in adult Americans: Results from the National Health and Nutrition Examination Survey. Neurogastroenterol Motil. 2020;00:e13789

14.- Bingham SA, Cummings JH (1989) Effect of exercise and physical fitness on large intestinal function. Gastroenterology 97: 1389-1399.

15.- lovino P, Chiarioni G, Bilancio G, et al. New onset of constipation during long-term physical inactivity: a proof-of-concept study on the immobility-induced bowel changes. PLoS One. 2013;8(8):e72608..

16.- Balanzá-Martínez V, Atienza-Carbonell B, Kapczinski F, et al. Lifestyle behaviours during the COVID-19time to connect. Acta Psychiatr Scand. 2020;141(5):399-400. 
17.- Scarmozzino F, Visioli F. Covid-19 and the subsequent lockdown modified dietary habits of almost half the population in an Italian sample. Foods. 2020;9(5):E675.

18.- Craig CL, Marshall AL, Sjöström M, et al. International physical activity questionnaire: 12-country reliability and validity. Med Sci Sports Exerc. 2003;35(8):1381 1395.

19.- Dubois $D$, Gilet $H$, Viala-Danten $M$, Tack J. Psychometric performance and clinical meaningfulness of the Patient Assessment of Constipation-Quality of Life questionnaire in prucalopride (RESOLOR) trials for chronic constipation. Neurogastroenterol Motil. 2010;22:e54-63.

20.- Ruiz-López MC, Coss-Adame E. Quality of life in patients with different constipation subtypes based on the Rome III criteria. Rev Gastroenterol Mex. 2015;80(1):13-20.

21.- Leung FW. Etiologic factors of chronic constipation: review of the scientific evidence. 2007 Dig Dis Sci 52: 313-316.

22.- Bliss MR. The rationale for sitting elderly patients in hospital out of bed for long periods is medically unsubstantiated and detrimental to their recovery. 2004 Med Hypotheses 62: 471-478.

23.- Strid H, Simrén M, Störsrud S, Stotzer PO, Sadik R. Effect of heavy exercise on gastrointestinal transit in endurance athletes. Scand J Gastroenterol. 2011;46(6):673-677.

24.- Costa RJ, Snipe RM, Kitic CM, Gibson PR. Systematic review: exercise-induced gastrointestinal syndrome-implications for health and intestinal disease. Aliment Pharmacol Ther. 2017;46(3):246-265.

25.- Moses FM. The effect of exercise on the gastrointestinal tract. Sports Med. 1990;9(3):159-172 .

26.- Anti M, Pignataro G, Armuzzi A, et al. Water supplementation enhances the effect of high-fiber diet on stool frequency and laxative consumption in adult patients with functional constipation. Hepatogastroenterology. 1998;45:727-732.

27.- Young RJ, Beerman LE, Vanderhoof JA. Increasing oral fluids in chronic constipation in children. Gastroenterol Nurs 1998, 21:156-161.

28.- Garg P. Psyllium Husk Should Be Taken at Higher Dose with Sufficient Water to Maximize Its Efficacy. J Acad Nutr Diet. 2017;117(5):681.

\section{Figures}




\section{Incidence of constipation during the lockdown}

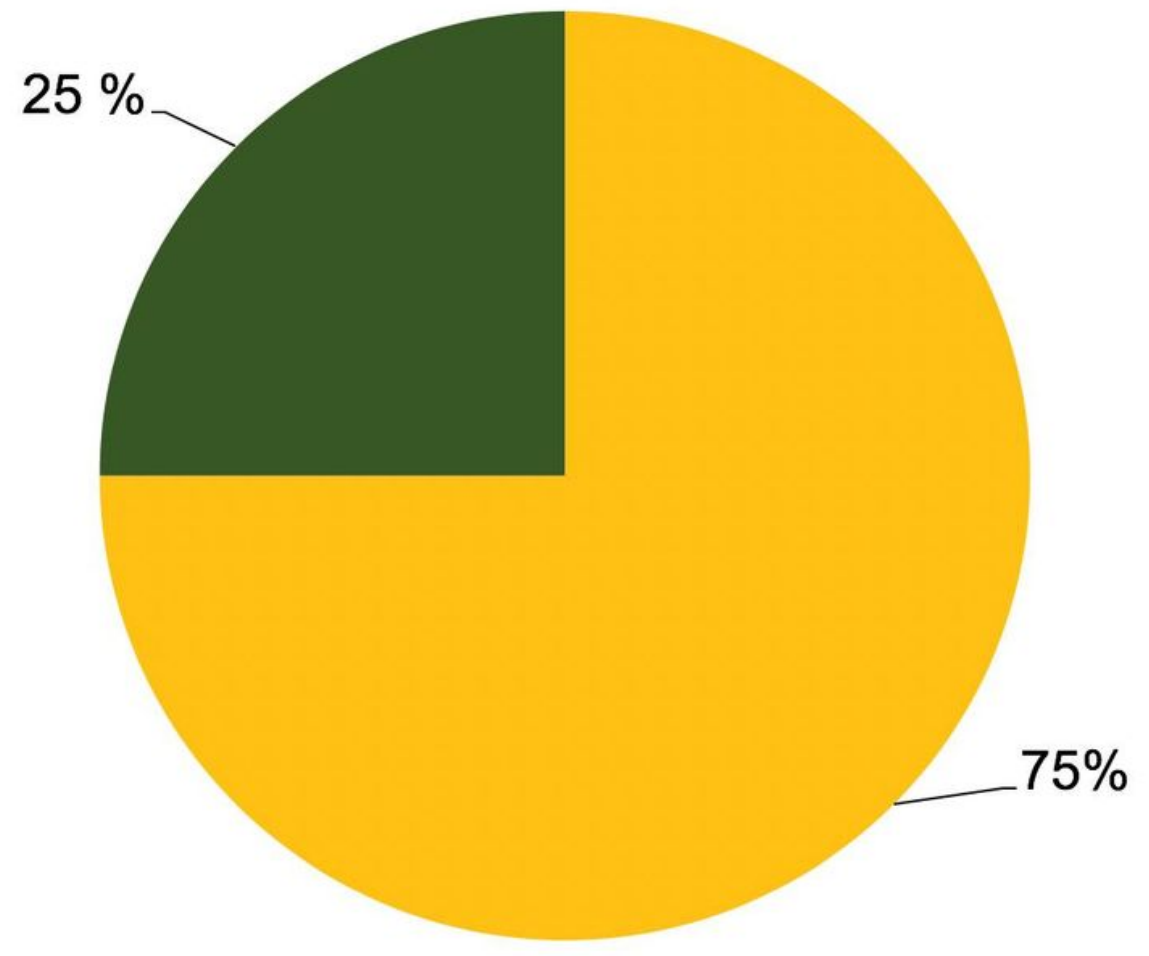

$\square$ No

- "New onset" constipation

\section{Figure 1}

Incidence of constipation during the lockdown

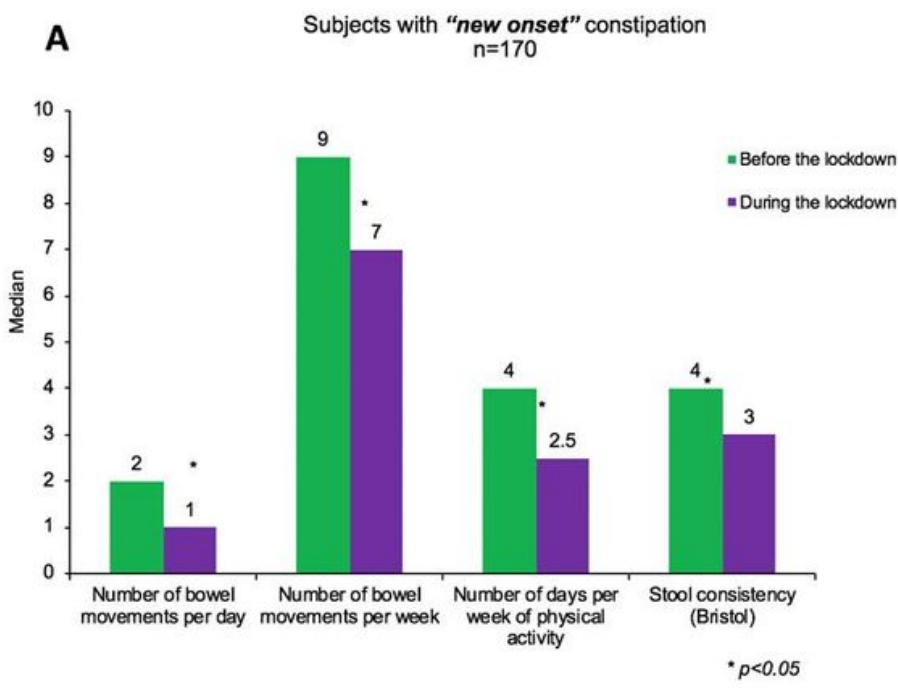

B

Subjects with no constipation

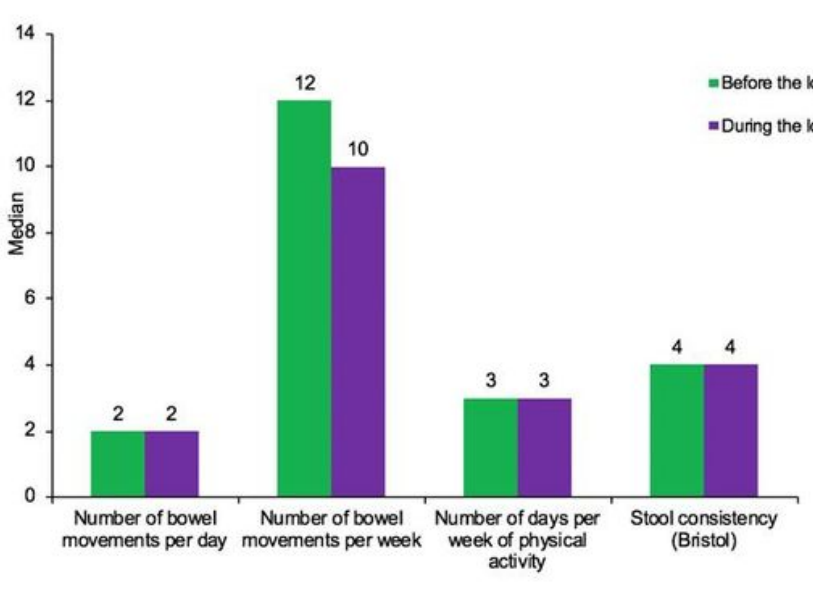

Figure 2

Number of bowel movements, days of physical activity and stool consistency before and after the lockdown 


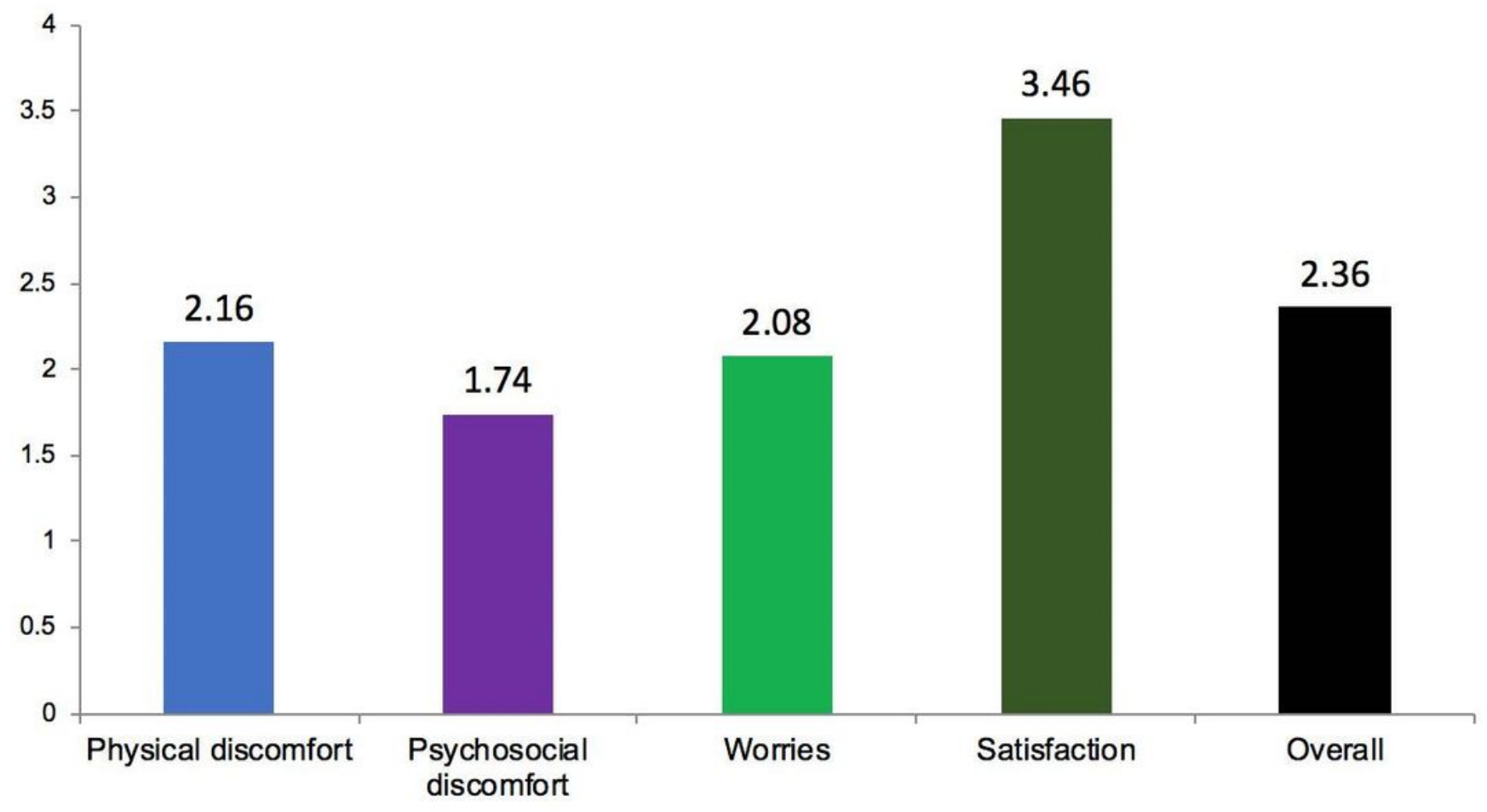

Figure 3

PAC-QOL subscales and overall score in subjects with "new onset" constipation 